\title{
From Achimota to Arusha: an ecumenical journey of Mission in Africa
}

\section{RESENHA}

EZEKIEL, Lesmore Gibson \& KEUM, Jooseop. From Achimota to Arusha: an ecumenical journey of Mission in Africa. Nairobi: Acton Publishers \& Geneva: WCC Publications, 2018. 179p. [De Achimota a Arusha: uma viagem missionária ecumênica na África.]

\section{BOOK REVIEW}

EZEKIEL, Lesmore Gibson \& KEUM, Jooseop. From Achimota to Arusha: an ecumenical journey of Mission in Africa. Nairobi: Acton Publishers \& Geneva: WCC Publications, 2018. 179p.

\section{RESEÑA}

EZEKIEL, Lesmore Gibson \& KEUM, Jooseop. From Achimota to Arusha: an ecumenical journey of Mission in Africa. Nairobi: Acton Publishers \& Geneva: WCC Publications, 2018. 179p. [De Achimota a Arusha: una viaje missionera en África]

\section{Graham McGeoch ${ }^{*}$}

Em preparação para a Conferência Mundial de Missão e Evangelismo em Arusha, Tanzania, 2018, o missiólogo africano, Lesmore Gibson Ezekiel e o teólogo sul-koreano, Jooseop Keum editaram um volume de artigos escritos por estudiosos e líderes religiosos africanos com o objetivo de oferecer "uma trajetória missionária desde Achimota até Arusha” (2018, p. X). A Conferência Mundial de Missão e Evangelismo reune especialistas e líderes cristãos para discutir e refletir sobre missão e evangelismo no mundo inteiro. Todos os continentes têm participação e o cristianismo, em toda sua expressão atual, está presente - Católico-Romano, Evangélico, Neo-Pentecostal, Ortodoxo, Pentecostal e Protestante.

A Conferência Mundial de Missão e Evangelismo é a herdeira do famoso Conselho Internacional Missionário que, por sua vez, é um resultado direto do encontro missionário histórico conhecido como Conferência Missionária de Edimburgo, em 1910. O Conselho Internacional Missionário reuniu-se

* Docente na Faculdade Unida de Vitória. 
pela primeira vez na África, em Achimota, Ghana, em 1958, um ano depois de Ghana se tornar independente. Naquela ocassião, o presidente Kwame Nkrumah discursou na conferência do Conselho Internacional Missionário, e a conferência mesma enfocou nos três 'auto' que, então, exercia influência no continente africano e em círculos missionários. Os três 'auto' são: autonomia no governo; autonomia na continuidade; e autonomia no sustento financiamento. As igrejas e agências missionárias (ocidentais) estavam num período de autoavaliação das suas práticas em meio às lutas descoloniais e as igrejas, frutos das missões (às vezes chamadas novas igrejas), buscavam uma nova direção.

Os tempos mudaram. Para a conferência em Arusha, em 2018, o volume editado por Gibson e Keum inclui artigos sobre o paradigma missiológico atual na África e discursa sobre temas importantes, tais como a relação entre cristianismo, islã e religiões tradicionais africanas; os debates duradouros sobre a relação entre evangelho e cultura (interesantemente vista pela ótica da tradução da Bíblia e a prática dos Pentecostais e das Igrejas Instituídas Africanas); e, também, oferencendo reflexões sobre questões relacionadas com gênero e raça. No entanto, há um capítulo interessante escrito por um arcebispo Ortodoxo sobre evangelismo na África. O arcebispo Makarios Tyllyrides (arcebispo kenyano da Igreja Ortodoxa Patriarcal (Grega) de Alexandria e toda África) escreve: "Existe uma missão principal da igreja: libertar o mundo do domínio de Satanás e da escravidão da morte e do pecado... Esta libertação é o evangelho autêntico para a humanidade. Portanto, o ministério de evangelização é um ministério de libertação" (2018, p. 139).

O capítulo escrito por Mercy Amba Odoyoye - fundadora do Círculo de Mulheres Teólogas Engajadas Africanas [Circle of Concerned African Women Theologians] - assinala não apenas sua própria história, mas a contribuição constante e importante das mulheres na obra teológica e missionária africana. Odoyoye é uma liderança africana inportantíssima em termos de formação teológica no continente. Os capítulos escritos por John Paul Issac e Viyani S. Vellem demonstram como especialistas africanos estão envolvidos numa variedade de escolas e perspectivas de pensamento (ou discursos) enquanto analisam seu contexto africano. Issac, um professor de missiologia, ensina na Namíbia, Alemanha, Estados Unidos e Suíça. Sua teologia segue a e dialoga com a teologia alemã numa forma de incultração africana deste pensar. Vellem, professor de teologia pública na África do Sul, dialoga com o pensamento pós-colonial e a teologia negra da libertação.

Este volume relaciona-se com o trabalho mais amplo da Conferência Mundial de Missão e Evangelismo, particularmente seu documento, 'Juntos 
pela Vida - missão e evangelismo em contextos em mudança' [Together Towards Life: mission and evangelism in changing landscapes] (2013)). O volume de Gibson e Keum avança e critica as perspectivas abertas pelo documento 'Juntos pela $V i d a$, dando continuidade às conversas no mundo inteiro provocadas pelo documento, publicado em 2013. O volume traz ao público mais amplo reflexões africanas sobre missão e evangelismo no seu continente.

O livro - em inglês - oferece uma introdução ao trabaho de estudiosos africanos e reflexões missiológicas contemporâneas no continente. Deveria ser de interesse de estudantes tanto quanto de membros de igrejas e agências missionárias em geral, que tenham interesse na África e nos temas da missão e evangelismo. 